\title{
REGULASI ZAKAT DAN PENERAPAN ZAKAT PRODUKTIF SEBAGAI PENUNJANG PEMBERDAYAAN MASYARAKAT (Studi Kasus pada Baitul Mal Kabupaten Aceh Utara)
}

\author{
Nasrullah \\ STAIN Malikussaleh Lhokseumawe \\ nasrullah_arull@yahoo.com
}

\begin{abstract}
Regulation and application of productive zakat on Baitul Mal North Aceh have a significant role to improve the welfare of society, in education, religion, economics and so on. The purpose of this research is to explain the regulation of zakat and charity productive application as supporting the prosperity of society. This research is a field research, conducted in North Aceb Regency Baitul Mal with qualitative form. Data obtained from interviews and documentation, then analyzed with descriptive. The results showed that the presence of Baitul Mal North Aceh Regency bound by a number of regulations (Qanun). Application of productive zakat is to provide working capital loans based on qard al-Hasan to motivate well and maximum effort. This program gives significant impact to support the prosperity of the community.
\end{abstract}

Keywords: Regulation, Zakat Productive, Community Empowerment

\begin{abstract}
Abstrak
Regulasi dan penerapan zakat produktif pada Baitul Mal Aceb Utara memiliki peran yang signifikan terhadap peningkatan kemakmuran masyarakat baik bidangpendidikan, keagamaan, ekonomi dan sebagainya. Tujuan penelitian adalab menjelaskan regulasi zakat dan penerapan zakat produktif sebagai penunjang kemakmuran masyarakat. Penelitian ini adalah field research, dilakukan di Baitul Mal Kabupaten Aceh Utara dengan bentuk kualitatif. Datanya didapatkan dari wawancara dan dokumentasi, kemudian dianalisis dengan deskriptif. Hasilpenelitian menunjukkan bahwa keberadaan Baitul Mal Kabupaten Aceb Utara diikat oleh sejumlah peraturan (Qanun). Penerapan zakat produktif adalab dengan memberikan pinjaman modal usaba berdasarkan qard al-basan untuk memotivasi usaha dengan baik dan maksimal. Program ini memberi dampak yang signifikan untuk penunjang kemakmuran masyarakat.
\end{abstract}

Kata Kunci: Regulasi, Zakat Produktif, Pemberdayaan Masyarakat 


\section{Pendahuluan}

Baitul Mal mempunyai makna sebagai sebuah lembaga atau tempat untuk menyimpan dan mengelola segala macam harta yang menjadi pendapatan Negara. Baitul Mal merupakan amanat Undang-Undang No. 11 Tahun 2006 tentang Pemerintah Aceh yang menegaskan bahwa zakat, harta wakaf dan harta agama dikelola oleh Baitul Mal Aceh dan Baitul Mal Kabupaten/Kota yang diatur dengan Qanun Aceh No. 10 Tahun 2007 tentang Baitul Mal. Pembentukan Baitul Mal di Aceh berkaitan dengan pembentukan lembaga zakat atau harta agama di daerah-daerah lain di Indonesia. Sejak tahun 1973 di Aceh telah dibentuk satu lembaga yang dinamakan Badan Penertiban Harta Agama (BPHA) dengan surat keputusan (SK) Gubernur Nomor 52 Tahun 1973 yang mengatur adanya lembaga ini, sejak dari Propinsi, Kabupaten/Kota, Kecamatan sampai BPHA Kampung. Pada tahun 1976, lembaga ini mengelola berbagai jenis harta agama seperti zakat, wakaf, infaq, dan harta-harta lainnya yang ditetapkan dengan peraturan-peraturan (Armiadi, 2008: 185).

Dengan dibentuknya lembaga Baitul Mal di Aceh khususnya Aceh Utara telah memberikan peluang yang cukup besar bagi masyarakat untuk mengaktualisasikan kekuatan yang ada pada dirinya untuk memperbaiki dan meningkatkan kondisi dan kualitas hidupnya. Peran-peran itu tidak dapat terlaksana dengan baik tanpa adanya institusi yang profesional dan mampu memanfaatkan peluang itu. Kehadiran Baitul Mal Aceh Utara adalah untuk mengisi peluang ini dan menjawab berbagai tantangan aktual yang dihadapi masyarakat Islam Aceh Utara dengan memanfaatkan kekuatan yang ada pada mereka sendiri, khususnya kekuatan ekonomi.

Dengan terbentuknya Baitul Mal Aceh Utara, diharapkan mampu berperan aktif dalam mengumpulkan dana dengan segala kemampuan yang ada dan dapat disalurkan kepada orang-orang yang berhak menerimanya, dengan harapan dapat menunjang perekonomian jangka panjang. Selama ini Baitul Mal Aceh Utara terus berupaya memacu pertumbuhan ekonomi masyarakat, salah satunya dengan memberikan zakat produktif. Zakat produktif adalah bagaimana harta zakat yang disalurkan kepada orang-orang yang berhak ini dapat dikembangkan lagi. Karena hakikat zakat itu 
bukanlah berapa rupiah yang diterima oleh para penerima zakat. Namun bagaimana zakat tersebut bisa meningkatkan kesejahteraan umat (Anne, 2008). Zakat produktif tersebut memiliki peran yang sangat penting dalam meningkatkan kemakmuran masyarakat Aceh, baik dalam bidang ekonomi, pendidikan, kesehatan, sosial dan kepentingan keagamaan.

Baitul Mal Kabupaten Aceh Utara pada awal Juni 2007 telah membentuk suatu visi pemberdayaan Harta Agama yang selanjutnya disebut sebagai Unit Pengelolaan Zakat Produktif (UPZP) untuk pemberdayaan ekonomi kaum dhu'afa. Hal ini sesuai dengan Qanun Aceh Nomor 10 Tahun 2007 tentang Baitul Mal, yaitu pasal 29 ayat (1) bahwa zakat didayagunakan untuk mustahik baik yang bersifat produktif maupun konsumtif berdasarkan ketentuan syari'at (Qanun, 2007).

Pada tahun yang sama, yaitu awal juni 2007 Baitul Mal Kabupaten Aceh Utara juga melakukan peluncuran produk alQard al-hasan dalam program pembiayaan modal usaha produktif bagi kaum fakir, miskin dan mualaf di beberapa Kecamatan dalam Kabupaten Aceh Utara dengan dana Rp.110.500.000,- (Seratus sepuluh juta lima ratus ribu rupiah), untuk 49 mustabik (Tim UPZP, 2007). Dan di tahun 2012 Baitul Mal Kabupaten Aceh Utara menyalurkan dana zakat untuk 138 mustahiq dengan dana sebesar Rp. 387.500.000,- (tiga ratus delapan puluh tujuh lima ratus ribu rupiah). Adapun sumber dana zakat yang dikelola oleh Baitul Mal kabupaten Aceh Utara berasal dari PNS, kontraktor, dan zakat pribadi. Dengan pendayagunaan zakat untuk usaha produktif diharapkan akan mampu mempercepat pertumbuhan ekonomi masyarakat.

Berdasarkan permaslahan yang dipaparkan di atas, maka peneliti bermaksud untuk mencari jawaban atas persoalan regulasi zakat, dan penerapan zakat produktif oleh Baitul Mal Aceh Utara sebagai penunjang pemberdayaan masyarakat. Persoalan ini sangat aktual untuk dikaji secara komperehensif, sehingga dapatmemberikan kontribusi terhadap pemberdayaan ekonomi bagi masyarakat Aceh umumnya dan Aceh Utara khususnya di masa depan. 


\section{Regulasi (Qanun) Zakat dan Baitul Mal}

Baitul Mal Aceh merupakan sebuah lembaga daerah nonstruktural yang diberi kewenangan untuk mengelola dan mengembangkan zakat, wakaf, dan harta agama lainnya dengan tujuan untuk kemaslahatan umat serta menjadi wali/wali pengawas terhadap anak yatim piatu dan/atau hartanya serta pengelolaan terhadap harta warisan yang tidak ada wali berdasarkan Syariat Islam (http:// baitulmal-bandaaceh)._Sebagai pihak penghimpun, pengelolaan dan penyaluran zakat, lembaga Baitul Mal diikat dengan suatu peraturan, seperti Qanun Aceh No. 10 Tahun 2007 tentang Baitul Mal.

Peran Baitul Mal oleh sebagian pakar mengatakan bahwa ia lebih berperan pada pengelolaan harta zakat secara pasif, yaitu berfungsi sebagai pihak penghimpun dana dan penyaluran kepada para mustahiq. Sementara Qanun tersebut telah menyatakan bahwa peran Baitul Mal Aceh tidak hanya berfungsi sebagai pengelola, tetapi juga mengembangkan zakat. Karena itu, upaya pengembangan zakat menjadi sesuatu yang amat penting, karena zakat tidak hanya sebagai masalah konsumtif, namun juga memperhatikan masalah yang produktif. Dalam artian bahwa harta zakat itu tidak hanya semata-mata untuk konsumtif saja, tetapi juga dapat dikembangkan dalam bentuk produktif lainnya, misalnya dijadikan suatu modal usaha agar dapat dimanfaatkan lebih luas dalam proses pengembagan masyarakat kedepan secara menyeluruh.

Sebagai potensi yang sangat besar bagi daerah, pemerintah memasukkan zakat sebagai sumber Pendapatan Asli Daerah (PAD). Beberapa ketentuan zakat sebagai PAD telah disahkan, seperti berawal dari UU No. 18 Tahun 2001 tentang Otonomi Khusus Nanggroe Aceh Darussalam (sebagai dasar awal munculnya masalah). Selanjutnya dikukuhkan kembali dalam UU No. 11 Tahun 2006 tentang Pemerintahan Aceh, yang tersebut dalam Pasal 180 ayat (1) huruf d, yaitu zakat. Dengan ketentuan ini meneguhkan peran negara dalam pengelolaan zakat, sebagai bagian pelaksanaan syari'at Islam. Ketentuan lanjutan adalah pada Qanun Aceh No. 10 Tahun 2007 tentang Baitul Mal, yaitu Pasal 24 ayat (2) bahwa semua penerimaan zakat yang dikelola Baitul Mal Aceh merupakan sumber PAD Aceh yang harus disetor ke Kas Umum Daerah Aceh. 
Demikian juga ketentuan Pasal 25 ayat (2) bahwa semua penerima zakat yang dikelola Baitul Mal Aceh merupakan sumber PAD Aceh yang harus disetor ke Kas Umum Daerah Kabupaten/Kota.

Peningkatan penghimpunan zakat sebagai PAD terkait erat dengan kebijakan pemerintah (Provinsi dan Kabupaten/Kota) terhadap regulasi dan manajemen Baitul Mal. Dari segi regulasi seperti disebutkan di atas, kemudian perangkat peraturan lainnya, yaitu Pergub tentang Mekanisme Pengelolaan Zakat dan Pergub Nomor 18 Tahun 2003 tentang Susunan Organisasi dan Tata Kerja Baitul Mal Aceh. Meskipun demikian, masalah mendasar yang dirasakan Baitul Mal tingkat Provinsi dan Kabupaten/Kota adalah belum mendukungnya manejemen kelembagaan untuk meningkatkan pendapatan zakat. Hal ini dapat dimaklumi bahwa Baitul Mal Aceh baru beroperasi Januari 2004, sementara Baitul Mal Kabupaten/Kota rata-rata baru beroperasi 2006. Akan tetapi Baitul Mal Kabupaten/ Kota yang baru diresmikan 2008 adalah Kota Sabang dan Kabupaten Aceh Tamiang. Bahkan Pemerintah Kabupaten Pidie Jaya dan Kota Sabulussalam hingga Januari 2009 belum membentuk Baitul Mal (http://www.sayedmuhammadhusen).

ZakatsebagaiPAD dalampengelolaannya menganutketentuan keuangan daerah, tanpa mempertimbangkan zakat sebagai bagian dari perintah agama. Padahal zakat dalam agama begitu terkumpul harus segera disalurkan. Tidak harus menunggu pengesahan APBA/ APBK, seperti PAD murni, karena yang dicairkan adalah uang zakat yang disetor ke kas daerah. Zakat yang disetor ke kas daerah menjadi PAD murni dianggap telah melanggar dengan prinsipprinsip syariah. Oleh karena itu, pencantuman zakat sebagai salah satu penerimaan PAD murni dalam berbagai ketentuan perundangundangan dengan segala akibat hukum yang melekat, khususnya peraturan keuangan daerah adalah bertentangan dengan esensi zakat yang sudah ditetapkan dalam al-Qur'ān (Amrullah, 2014).

Salah satu indikator menguatnya peran Baitul Mal dapat dilihat dari kemampuan menghimpun dana zakat dan infak. Dari data yang ada, Baitul Mal Aceh menghimpun zakat dan infak tahun 2011 Rp 26,60 miliar, tahun 2012 Rp 28,78 miliar dan tahun 2013 Rp 39,3 miliar. Sementara 23 Baitul Mal Kab/Kota menghimpun 
zakat dan infak tahun $2011 \mathrm{Rp} 77,57$ miliar, tahun $2012 \mathrm{Rp} 98,19$ miliar dan tahun 2013 Rp 101,68 miliar. Seluruh dana itu disalurkan 90\% lebih untuk penanggulangan kemiskinan dan pemberdayaan kaum dhuafa (http://baitulmal.aceh).

\section{Zakat Produktif}

Zakat produktif adalah harta zakat yang disalurkan kepada orangorang yang berhak dan dapat diberdayagunakan. Karena hakikat zakat bukanlah berapa rupiah yang diterima oleh para penerima zakat (mustahiq), namun bagaimana zakat tersebut bisa meningkatkan kesejahteraan umat. Zakat produktif merupakan sumber dana potensial yang dapat dimanfaatkan untuk memajukan kesejahteraan umum bagi seluruh masyarakat (Armiadi, 2008: 67). Sedangkan (Hafidhuddin 2002: 27) menyebutkan bahwa zakat produktif adalah zakat yang diberikan kepada mustahiq sebagai modal untuk menjalankan suatu kegiatan ekonomi, yaitu untuk menumbuh kembangkan tingkat ekonomi dan potensi produktifitas mustahiq. Tidak jauh berbeda dengan Anwar (2010) bahwa zakat produktif merupakan pengelolaan dan penyaluran zakat secara produktif yang mempunyai efek jangka panjang bagi para penerima zakat.

Jadi zakat produktif adalah harta yang berkembang (produktif atau berpotensi produktif), yang dimaksud dengan harta yang berkembang di sini adalah harta tersebut dapat bertambah dan berkembang bila dijadikan modal usaha atau mempunyai potensi untuk berkembang, misalnya hasil pertanian, perdagangan, ternak, emas, perak, dan uang. Pengertian berkembang menurut istilah yang lebih luas adalah sifat harta tersebut dapat memberikan keuntungan atau pendapatan lain. Zakat ini dimaksudkan agar mustahiq dapat berusaha dan bekerja lebih maksimal dalam memenuhi kebutuhan hidupnya. Pada akhirnya, diharapkan mustahiq dapat meningkatkan pendapatannya sehingga mereka tidak lagi menjadi mustahiq bahkan mungkin selanjutnya dapat menjadi muzakki. Selain itu, penyaluran zakat secara produktif juga dapat menghilangkan sifat bermalasmalasan dengan hanya mengharapkan bantuan dari orang lain. Penyaluran zakat secara produktif menuntut mustahiq untuk lebih profesional dalam mengelola hartanya. Model distribusi zakat 
produktif untuk modal usaha akan lebih bermakna, karena akan menciptakan sebuah mata pencaharian yang akan mengangkat kondisi ekonomi para mustahiq, sehingga diharapkan lambat laun mereka akan dapat keluar dari jerat kemiskinan, lebih dari itu mereka dapat mengembangkan usaha sehingga dapat menjadi seorang muzakki.

Dasar hukum zakat produktif adalah berdalil kepada hadīth yang diriwayatkan oleh Muslim, yaitu ketika Rasulullah memberikan uang zakat kepada 'Umar bin al-Khatțāb yang bertindak sebagai amil zakat seraya bersabda (Zeinuddin; 1986: 516-517):

\section{عَنْ عُمَرَبْنِ الخَطَابِ رَضِيَ اللهُ عَنْهُ قَالَ كَانَ رَسُوْلُ اللهِ صَلَّى اللهُ عَلَيْهِه وَسَلَّمَ

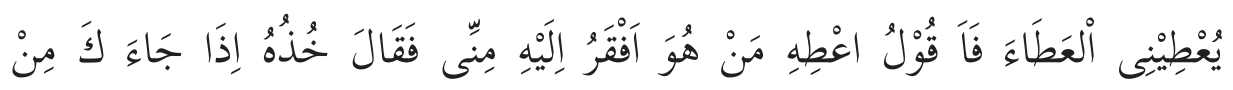

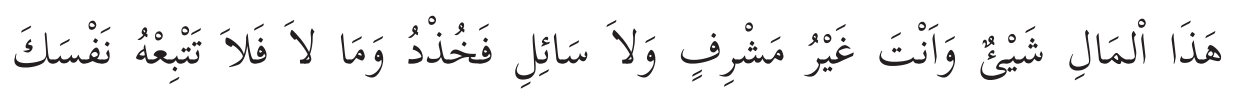

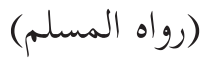

"Dari Umar bin Khatab ra berkata: Rasulullah saw. memberikan pemberian kepadaku, lalu saya berkata kepada beliau: Berikanlah kepada orang yang lebih memerlukannya dari pada saya". Beliau bersabda "Ambillah itu (kembangkanlah), apabila ada sesuatu yang datang kepadamu dari harta ini sedangkan kamu tidak melekat (untuk mengambilnya) dan tidak meminta maka ambillah ia. Sesuatu yang tidak (seperti itu) maka janganlah kamu ikutkan dirimu padanya (HR. Muslim).

Hadìth di atas memberikan pengertian bahwa harta zakat dapat dikembangkan dan diusahakan, hal ini sebagai suatu indikasi bahwa harta zakat dapat digunakan untuk hal-hal selain kebutuhan konsumtif, semisal usaha yang menghasilkan keuntungan (produktif). Rasulullah saw. bersabda:

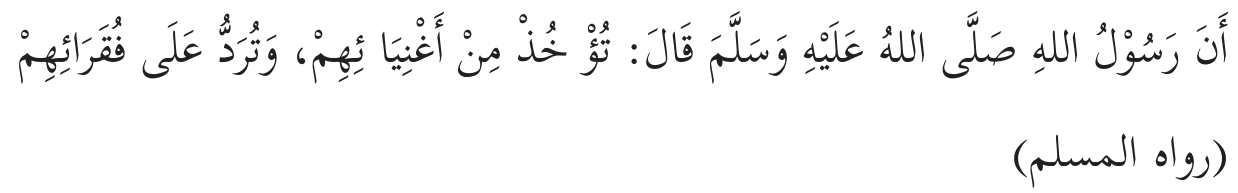


Zakat diambil dari orang kaya di antara mereka kemudian diserahkan kepada orang miskin di antara mereka. (HR. Muslim)

Hadis lain yang berkenaan dengan zakat yang didistribusikan dengan usaha produktif adalah hadis yang dikutip oleh Qardhawi (2007: 564), yaitu yang diriwayatkan dari Anas bin Malik, yang berbunyi:

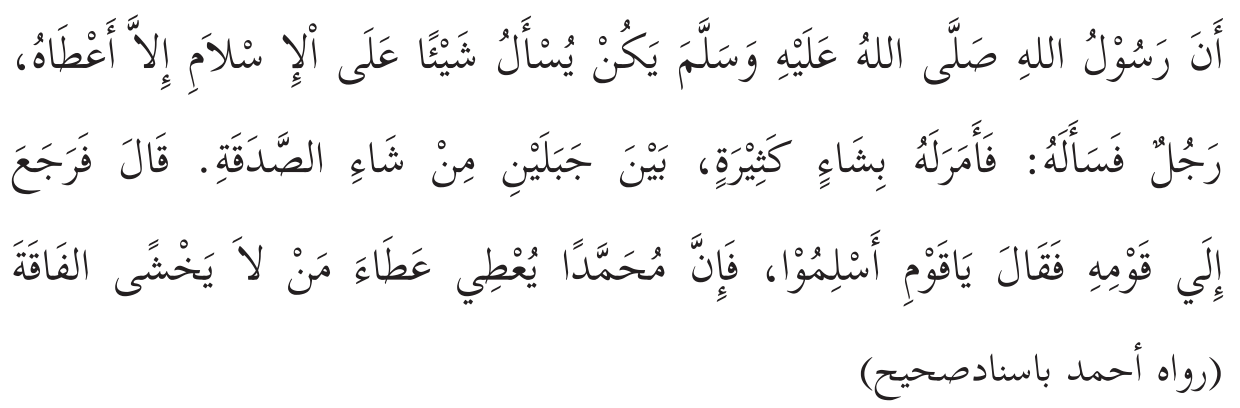

"Bahwasanya Rasulullah saw. tidak pernah menolak jika diminta sesuatu atas nama Islam, maka Anas berkata "suatu ketika datanglah seorang laki-laki dan meminta sesuatu kepada beliau, maka beliau memerintahkan untuk memberikan kepadanya domba (kambing) yang jumlahnya sangat banyak yang terletak dua gunung dari harta shadaqah, lalu laki-laki itu kembali kepada kaumnya seraya berkata "wahai kaumku masuklah kalian ke dalam Islam, sesungguhnya Muhammad telah memberikan suatu pemberian yang dia tidak takut jadi kekurangan" (HR. Aḥmad dengan sanad șạ̣ị̣̣)

Pemberian kambing kepada muallafah qulübubum di atas adalah sebagai bukti bahwa harta zakat dapat disalurkan dalam bentuk modal usaha. Nabi saw. juga pernah mengisyaratkan dalam sabdanya:

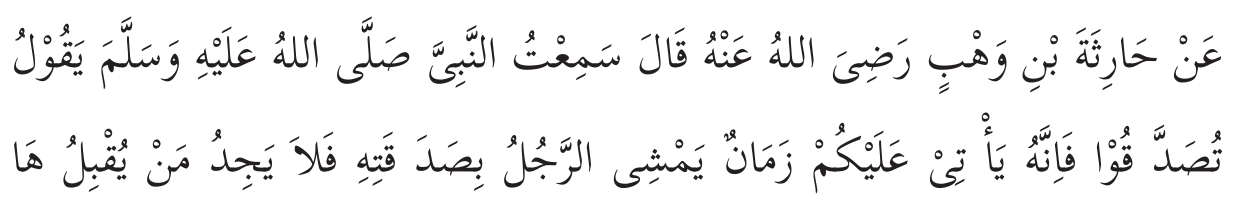


Dari Harithah bin Wahb ra. Berkata, ia merdengar Rasulullah saw. Bersabda: "Berzakatlah kalian, niscaya akan datang suatu masa, di mana seorang muzakki (pembayar zakat), membawa zakat hartanya, tetapi tidak menemukan lagi orang yang berhak menerimanya. (HR. Muslim)

Polapendistribusianzakatproduktif haruslahdiatursedemikian rupa sehingga jangan sampai sasaran dari program ini tidak tercapai. Beberapa langkah yang menjadi acuan dalam pendistribusian zakat produktif (Armiadi, 2008: 69) diantaranya adalah: (a)Forecasting yaitu meramalkan, memproyeksikan dan mengadakan taksiran sebelum pemberian zakat. (b) Planning yaitu merumuskan dan merencanakan suatu tindakan tentang apa saja yang akan dilaksanakan untuk tercapainya program, seperti penentuan orang-orang yang akan mendapat zakat produktif, menentukan tujuan yang ingin dicapai, dan lain-lain. (c) Organizing dan Leading yaitu mengumpulkan berbagai elemen yang akan membawa kesuksesan program termasuk di dalamnya membuat peraturan yang baku yang harus ditaati. (d) Controlling yaitu pengawasan terhadap jalannya program sehingga jika ada sesuatu yang tidak beres atau menyimpang dari prosedur akan segera terdeteksi.

Selain langkah-langkah tersebut di atas bahwa dalam penyaluran zakat produktif haruslah diperhatikan orang-orang yang akan menerimanya, apakah dia benar-benar termasuk orang-orang yang berhak menerima zakat dari golongan fakir miskin, demikian juga mereka adalah orang-orang yang berkeinginan kuat untuk bekerja dan berusaha. Masjfuk Zuhdi menyebutkan bahwa seleksi bagi para penerima zakat produktif haruslah dilakukan secara ketat, sebab banyak orang fakir miskin yang masih jasmani dan rohaninya tetapi mereka malas bekerja. Mereka lebih suka jadi gelandangan daripada menjadi buruh atau karyawan. Mereka itu tidak boleh diberi zakat, tetapi cukup diberi sedekah ala kadarnya, karena mereka merusak citra Islam. Karena itu fakir miskin itu harus diseleksi lebih dahulu, kemudian diberi pelatihan keterampilan yang sesuai dengan bakatnya, kemudian baru diberi modal kerja yang memadai.

Sri Adi Bramasetia, Sekretaris Jenderal Asosiasi Organisasi Pengelola Zakat Indonesia (Forum Zakat atau FOZ) menyatakan 
bahwa calon penerima zakat harus diajarkan tentang manajemen keuangan yang baik, sehingga mereka bisa menghitung berapa persentase modal yang akan dikelola, berapa labanya dan berapa persen yang akan mereka konsumsi. Jika semua proses itu tidak terpenuhi, maka dana zakat tidak akan produktif melainkan konsumtif.

Menurut Didin Hafidhuddin Badan Amil Zakat (BAZ) atau Lembaga Amil Zakat (LAZ), jika memberikan zakat yang bersifat produktif, harus pula melakukan pembinaan dan pendampingan kepada para mustahik agar kegiatan usahanya dapat berjalan, seperti memberi pembinaan rohani dan intelektual keagamaan agar semakin meningkat kualitas keimanan dan keIslamannya (Hafidhuddin; 2002:45). Orang miskin harus dibebaskan lebih dahulu dari kemiskinan jiwanya sehingga tidak mudah untuk meminta-minta, sasaran utama adalah membuat jiwa si miskin menjadi kaya dan siap berusaha. Setelah itu baru digulirkan dana zakat tersebut. Namun mereka tidak berjalan sendiri-sendiri melainkan dikelompokkan sehingga bisa membantu antar anggota kelompoknya dan bahkan membantu kelompok yang lain. Karena itu, dana zakat diberikan kepada mustahiq yang memiliki sisi pemberdayaan.

\section{Metode Penelitian}

Jenis penelitian ini adalah penelitian kualitatif (Moleong, 1989: 2 dan Parsudi; 1994: 8) yang berbentuk penelitian lapangan (field research), yaitu pada Badan Baitul Mal Kabupaten Aceh Utara. Data primer didapatkan dari sumber pertama baik dari Baitul Mal maupun penerima zakat produktif, yaitu dengan melakukan wawancara secara langsung dan mendalam (Sumardi; 2006: 49). Sedangkan analisis yang digunakan adalah analisis deskriptif, yaitu menggambarkan dan meringkaskan berbagai kondisi, situasi atau berbagai variabel.

\section{Analisis}

Sejarah Pembentukan Baitul Mal Kabupaten Aceh Utara

Orde reformasi memberikan angin pembaharuan dalam berbagai segi kehidupan masyarakat Indonesia pada umumnya 
dan masyarakat Aceh pada khususnya. Sebagai salah satu wujud perubahan yang terjadi selama orde reformasi adalah disahkan Undang-Undang Nomor 38 Tahun 1999 tentang Pengelolaan Zakat. Undang-Undang yang disahkan pada tanggal 23 September 1999 ini menjadi dasar hukum yang tertinggi tentang pengelolaan zakat dalam tatanan Perundang-undangan Negara.

Walaupun demikian, keberadaan Undang-Undang saja tidaklah cukup untuk melakukan pengelolaan zakat secara baik dan benar. Oleh karena itu, dibutuhkan aturan-aturan lain yang mengatur secara teknis. Bentuk pengelolaan zakat khususnya untuk Propinsi Aceh. Di dalam Undang-Undang Nomor 44 Tahun 1999 tersebut tepatnya dalam pasal 5 ayat (1) disebutkan "Penyelenggaraan kehidupan beragama diwujudkan dengan bentuk pelaksaan Syari'at Islam bagi pemeluknya dalam bermasyarakat".

Pada tahun 2000 pemerintah Aceh mengeluarkan Qanun Nomor 5 Tahun 2000 tentang Pelaksaan Syar'iat Islam. Salah satu bidang pelaksanaan Syari'at Islam menurut qanun tersebut adalah pembentukan Baitul Mal. Seiring pembentukan Baitul Mal di tingkat propinsi, maka pemerintah Kabupaten/Kota juga membentuk Baitul Mal sebagai lembaga yang melaksanakan ketentuan undangundang dan peraturan daerah yang telah disebutkan di atas.

Di Kabupaten Aceh Utara pembentukan Baitul Mal dilakukan melalui Surat Keputusan Bupati Kabupaten Aceh Utara Nomor 22 Tahun 2004 tentang pembentukan susunan organisasi dan tata kerja Baitul Mal Kabupaten Aceh Utara Surat Keputusan ini dikeluarkan pada tanggal 10 Februari 2004. Dengan dikeluarkannya keputusan tersebut maka Baitul Mal Aceh Utara secara resmi berdiri. Dengan berdirinya Baitul Mal Aceh Utara, maka Badan Amil Zakat, Infak dan Sadakah (BAZIS) Kabupaten Aceh Utara secara resmi dihapus. Adapun asset yang dimiliki oleh BAZIS kabupaten Aceh Utara beralih kepemilikannya menjadi milik Baitul Mal Kabupaten Aceh Utara.

Penggantian BAZIS dengan Baitul Mal bukan hanya bentuk penggantian nama. Ruang lingkup BAZIS geraknya hanya terbatas pada pengelolaan zakat, infak dan shadaqah saja. Adapun Baitul Mal memiliki tugas dan fungsi yang lebih luas. Baitul Mal tidak hanya mengelola zakat, namun juga direncanakan akan menjadi suatu 
lembaga yang berfungsi mengelola segala pendapatan daerah di luar Anggaran Pendapatan dan Belanja Daerah (APBD).

\section{Peran Zakat Produktif dan Lembaga Pengelolaan Zakat}

Sekarang ini pengelolaan zakat di Indonesia, makin lama makin tumbuh dan berkembang (Ali; 1988: 52-53). Zakat yang diberikan kepada mustahik akan berperan sebagai pendukung peningkatan ekonomi mereka apabila dikonsumsikan pada kegiatan produktif. Pendayagunaan zakat produktif sesungguhnya mempunyai konsep perencanaan dan pelaksanaan yang cermat seperti mengkaji penyebab kemiskinan, ketidakadaan modal kerja, dan kekurangan lapangan kerja, dengan adanya masalah tersebut maka perlu adanya perencanaan yang dapat mengembangkan zakat bersifat produktif tersebut.

Pengembangan zakat bersifat produktif dengan cara dijadikannya dana zakat sebagai modal usaha, untuk pemberdayaan ekonomi penerimanya, dan supaya fakir miskin dapat menjalankan atau membiayai kehidupannya secara konsisten. Dengan dana zakat tersebut fakir miskin akan mendapatkan penghasilan tetap, meningkatkan usaha, mengembangkan usaha serta mereka dapat menyisihkan penghasilannya untuk menabung.

Dana zakat untuk kegiatan produktif akan lebih optimal bila dilaksanakan Lembaga Amil Zakat karena LAZ sebagai organisasi yang terpercaya untuk pengalokasian, pendayagunaan, dan pendistribusian dana zakat, mereka tidak memberikan zakat begitu saja melainkan mereka mendampingi, memberikan pengarahan serta pelatihan agar dana zakat tersebut benar-benar dijadikan modal kerja sehingga penerima zakat tersebut memperoleh pendapatan yang layak dan mandiri (Sartika; 2008).

Dengan berkembangnya usaha kecil menengah dengan modal berasal dari zakat akan menyerap tenaga kerja. Hal ini berarti angka pengangguran bisa dikurangi, berkurangnya angka pengangguran akan berdampak pada meningkatnya daya beli masyarakat terhadap suatu produk barang ataupun jasa, meningkatnya daya beli masyarakat akan diikuti oleh pertumbuhan produksi, pertumbuhan sektor produksi inilah yang akan menjadi salah satu indikator adanya 
pertumbuhan ekonomi. Dengan gambaran tersebut, maka peranan zakat sangat signifikan dalam kehidupan manusia. Dimana zakat merupakan suatu penggerak atau motor yang berpotensi memberikan tunjangan kepada para pedagangataupun profesi lain yang membutuhkan modal, yang tidak bisa didapatkan dari jalan lain.

Menyalurkan zakat melalui Baitul Mal akan jauh lebih efektif daripada menyalurkannya secara orang perorang. Menyerahkan zakat kepada petugas zakat merupakan hal yang biasa dilakukan Rasulullah saw. dan para sahabat sesudahnya (Qardhawi; 2005: 545). Bahkan para ulama sesudahnya pun tetap mengwajibkan penyerahan pengurusan dan pengelolaan zakat kepada para petugas. Ada beberapa keuntungan yang bisa didapat dengan menyalurkan zakat kepada Lembaga Pengelola zakat yang tidak akan diperoleh dengan membayar secara langsung oleh muzakki kepada mustahik zakat diantaranya yaitu: (1) Menjamin kepastian dan disiplin muzakki dalam membayar zakat. (2) Untuk menjaga perasaan rendah diri para mustahik.(3) Memperlihatkan syiar Islam.(4) Untuk mencapai efisiensi dan efektifitas, serta sasaran yang tepat dalam penggunaan dana zakat menurut skala prioritas. (5) Dapat digunakan untuk kemaslahatan umat Islam secara umum yang memerlukan dana yang tidak sedikit. Seperti mengantisipasi upaya pemurtadan dari pihak luar, upaya pembinaan kaum dhuafa baik dari segi ekonomi maupun pendidikannya, jihad melawan kaum kafir yang memerangi umat Islam sebagaimana yang terjadi di beberapa wilayah yang ada di dunia (Hafidhuddin; 2002:55).

Jika zakat diserahkan langsung dari muzakki kepada mustahik, meskipun secara hukum syari'ah adalah sah, akan tetapi disamping akan terabaikannya hal-hal tersebut di atas juga hikmah dan fungsi zakat, terutama yang berkaitan dengan kesejahteraan umat secara umum akan sulit diwujudkan.

\section{Penerapan Zakat Produktif}

Baitul Mal Kabupaten Aceh Utara pada awal Juni 2007 telah membentuk suatu divisi pemberdayaan Harta Agama yang selanjutnya disebut sebagai Unit Pengelolaan Zakat Produktif (UPZP) untuk pemberdayaan ekonomi kaum dhuafa. Hal ini sesuai 
dengan Qanun Aceh Nomor 10 Tahun 2007 tentang Baitul Mal pasal 29 ayat (1) yaitu zakat didayagunakan untuk mustahik baik yang bersifat produktif maupun konsumtif berdasarkan ketentuan syari'at.

Kepengurusan UPZP langsung dibimbing oleh Kepala Badan Baitul Mal Kabupaten Aceh Utara untuk memahami maksud dan makna zakat yang wajib ditunaikan oleh muzakki maupun yang dikeluarkan untuk diberikan kepada mustahiq. Staf UPZP telah diberikan kewenangan untuk memberdayakan harta agama (zakat) kepada mustahiq untuk dikelola sebagai modal usaha (zakat produktif) dari dana zakat yang terkumpul di Baitul Mal Kabupaten Aceh Utara.

Penerapan pemberdayaan ekonomi kaum dhuafa melalui pemberian modal usaha (zakat produktif) dimaksudkan untuk meningkatkan taraf hidup ekonomi keluarga serta mendidik tidak malas bekerja serta tidak mengharapkan pemberian cuma-cuma dari orang lain. Untuk maksud tersebut mereka diharuskan membayar angsuran setiap bulannya (sektor perdagangan), atau sesuai dengan masa panennya (sektor pertanian dan peternakan). Ansuran yang dikembalikan tersebut, selanjutnya digulirkan kembali kepada mereka yang membutuhkan. Sistem ini telah mendidik mereka untuk tidak selamanya menjadi mustahiq tetapi diharapkan nantinya menjadi muzakki apabila sudah cukup berhasil (Tim UPZP Baitul Mal, 2007: 1).

Berdasarkan data laporan (Tim UPZP, 2012) bahwa Baitul Mal Kabupaten Aceh Utara pada awal Juni 2007 telah melakukan peluncuran produk al-Qard al-Hasan dalam program pembiayaan modal usaha produktif bagi kaum fakir, miskin dan muallaf di beberapa Kecamatan dalam Kabupaten Aceh Utara dengan dana Rp. 110.500.000,- (Seratus sepuluh juta lima ratus ribu rupiah), untuk 49 mustahiq. Pada tahun 2008 sebanyak 325 mustahiq, tahun 2009 sebanyak 487 mustahiq, tahun 2010 sebanyak 166 mustahiq dan pada tahun 2011 sebanyak 138 mustahiq dengan dana sebesar Rp. 387.500.000,- (tiga ratus delapan puluh tujuh lima ratus ribu rupiah), yang terdiri dari dana yang bergulir Rp. 175.000.000,- (seratus tujuh puluh lima juta rupiah) dan dana murni Rp. 212.000.000,- (dua ratus dua belas juta rupiah), dengan nilai yang beragam sesuai dengan 
usaha yang mereka lakukan. Program ini diharapkan terus berlanjut sebagai upaya peningkatan dalam pembinaan zakat produktif agar lebih meluas. Dan pada tahun 2012 Baitul Mal Kabupaten Aceh Utara menyalurkan dana zakat untuk 138 mustahik dengan dana sebesar Rp. 387.500.000,- (tiga ratus delapan puluh tujuh lima ratus ribu rupiah).

Baitul Mal Kabupaten Aceh Utara juga melayani masyarakat yang berada di luar Kabupaten Aceh Utara, seperti masyarakat Kota Lhokseumawe. Namun untuk masyarakat di luar Kabupaten Aceh Utara dikhususkan hanya untuk individu saja sedangkan yang berkelompok tidak dilayani karena sudah termasuk wilayah luar Kabupaten Aceh Utara. Program pemberdayaan ekonomi kaum masyarakat miskin melalui pemberdayaan modal untuk usaha produktif dimaksudkan untuk menunjang kemakmuran masyarakat diantaranya meningkatkan taraf hidup ekonomi keluarga dan mendidik tidak malas bekerja serta tidak mengharapkan pemberian cuma-cuma dari orang lain.

Dengan adanya modal usaha tersebut mustahiq dapat menjalankan usahanya yang sedang kekurangan modal dan diharapkan dikembangkan dan dimanfaatkan semaksimal mungkin serta dapat mengembalikan ansuran sesuai dengan kesepakatan setiap bulannya. Modal yang dikembalikan tersebut, selanjutnya digulirkan kembali kepada mereka yang membutuhkan. Sistem ini telah mendidik mereka untuk tidak selamanya menjadi mustahiq tetapi diharapkan nantinya mereka menjadi muzakki apabila sudah cukup berhasil.

\section{Langkah-langkah Pengelolaan Dana Zakat Produktif}

Sebagaimanayangtelah diuraikan sebelumnyabahwapersoalan permodalan dana zakat bisa dikelompokkan kepada usaha untuk memenuhi kebutuhan azasi masyarakat miskin. Zakat produktif tetap bisa dilakukan walaupun koleksi dana zakat tidak banyak atau belum mengalami surplus atau keperluan dasar masyarakat miskin belum terpenuhi. Yang terpenting adalah permodalan dana zakat seperti ini haruslah ditujukan untuk kemaslahatan golongan masyarakat mustahiq sesuai dengan ketentuan syara'. Karena itu 
sudah sewajarnya model distribusi zakat ini dikembangkan untuk masa depan untuk meningkatkan ekonomi mustahik. Oleh karena itu memerlukan langkah-langkah yang bisa diaplikasikan di lapangan, diantaranya (Tim UPZP, 2008: 1) sebagai berikut:

1. Model Permodalan Zakat dalam Skim Qard al-Hasan, dalam sistem ini amil bertindak sebagai pihak yang meminjamkan modal (berpiutang) dan mustahiq bertindak sebagai pihak peminjam (berhutang). Aplikasinya adalah amil meminjamkan sejumlah dana kepada mustahiq untuk dipakai sebagai modal usaha dengan kewajiban mengembalikan pinjaman tersebut tanpa bunga, adapun dalam jangka waktu ansuran disesuaikan dengan keadaan dan kemampuan mustahiq. Penyesuaian dengan keadaan dan kemampuan mustahiq dalam jangka waktu inilah yang membedakan sistem qard al-hasan dengan sistem pinjaman lain. karena itu qard al-hasan bisa disebut dengan pinjaman lunak (soft and benevolent load), karena dipakai ketika ada peminjaman yang di dalamnya terkandung banyak kebaikan dan toleransi, seperti jangka waktu pengembalian yang relatif lama dan besarnya ansuran itu disesuaikan dengan kemampuan si peminjam (mustahiq).

Sedangkan dana ansuran dari mustahiq tersebut harus segera disalurkan kepada mustahiq lain yang sebelumnya hak mereka tertunda. Dengan kata lain dana ansuran tersebut tidak boleh dimasukkan ke dalam kas Baitul Mal untuk disimpan atau menjadi milik lembaga tersebut ataupun menjadi milik amil. Dengan demikian dana-dana yang digulir ini tetap saja menjadi milik mustahiq secara bergiliran atau dengan kata lain amil hanya bertindak sebagai mediator.

2. Aplikasi Modal Zakat Melalui Akad Mud̄arabah, Aplikasi zakat sebagai modal usaha dalam sistem ini adalah amil bertindak sebagai pemilik modal (șähib al-mā̄), sedangkan mustahiq sebagai pengelola (mustahiq). Amil memberikan harta zakat kepada mustahiq untuk digunakan sebagai modal dalam suatu usaha. Jika ada persyaratan tertentu dalam akad mud̦ārabah, seperti jenis usaha, tempat usaha, objek usaha dan sebagainya maka disebut dengan mud̄ārabah muțlaqah. 
Sistem ini dikenal dengan sistem bagi hasil dan bagi rugi (profit and loss sharing). Karena itu kedua belah pihak mesti memiliki kesepakatan tentang presentase keuntungan usaha, misalnya $20 \%$ untuk amil dan $80 \%$ untuk mustahiq. Keuntungan tersebut harus dimasukkan dalam pendapatan lembaga zakat dan dapat disalurkan kembali kepada mustahiq yang lain. Akan tetapi jika usaha tersebut mengalami kerugian, maka hal itu ditanggung bersama, artinya pihak amil tidak menuntut harta apapun termasuk modal dari mustahiq yang mengalami kerugian dalam usahanya (Tim UPZP, 2008: 6).

3. Aplikasi Permodalan Zakat Melalui Akad Murābaḥah, dalam sistem ini pihak amil bertindak sebagai penjual, sedangkan mustahiq bertindak sebagai pembeli. Pihak amil menjual sebuah produk kepada mustahiq dengan pembayaran sebesar harga modal ditambah keuntungan yang disanggupi oleh mustabik berdasarkan kemampuannya. Misalnya, harga modal sebuah mesin jahit sebesar Rp 3.000.000,- dan mustahiq hanya sanggup memberikan keuntungan sebesar Rp 50.000,-. Berarti mustahiq mesti membayar sebuah mesin jahit seharga 3.050.000,-. Kemudian untuk memudahkan mustahik, pembayaran hendaknya dilakukan dengan sistem kredit (ansuran) yang lama waktunya disesuaikan dengan keadaan mustahiq. Misalnya, dari dana yang harus dibayar tersebut mustahiq hanya mampu membayar ansuran Rp. 75.000,- perbulan. Berarti mustahiq dapat menyelesaikan pembayarannya selama 3 tahun 4 bulan.

Jika amil tidak memiliki asset produk yang diperlukan oleh mustahiq pada saat transaksi, maka amil bisa melakukan sistem murābahah dengan pemesan pembelian (KPP). Hal. Ini berarti pihak amil mengadakan barang (produk) untuk memenuhi kebutuhan mustahiq yang memesannya. Adapun keuntungan dari praktek ini tetap akan digulirkan sebagai modal baru kepada mustahiq lain dan begitu seterusnya.

Dari tiga langkah-langkah yang bisa diterapkan/diaplikasikan di atas nampak bahwa ansuran yang diperoleh dan keuntungan yang didapatkan bukan milik lembaga zakat, amil hanyalah bertindak sebagai mediator yang berusaha mengurus perputaran modal agar berkembang dan berhasil, sehingga tujuan dari pemanfaatan 
dana zakat untuk menunjang kemakmuran masyarakat benarbenar dapat diwujudkan. Dari sini juga menunjukkan bahwa permodalan dana zakat untuk usaha produktif menjadi satu bentuk atau model distribusi bagi peningkatan kemakmuran masyarakat, karena bantuan permodalan merupakan kunci bagi menggerakkan sektor rill dalam perekonomian khususnya masyarakat miskin.

\section{Ruang Lingkup Kegiatan Unit Pengelola Zakat Produktif (UPZP)}

a. Pendataan, Penyeleksian dan Sosialisasi, dalam pemberdayaan modal usaha ini tim UPZP bekerjasama dengan kelompok pendamping di dalam wilayah kerja Kecamatan-kecamatan dengan berbagai elemen masyarakat seperti PSM, Baitul Qiradh, LSM/Yayasan atau Lembaga Keagamaan seperti Dayah/Bp dan juga Kelompok Perorangan.

Awal pemberian modal usaha kepada masyarakat, tim UPZP melakukan survei kelapangan dan melakukan sosialisasi program dengan calon pendamping untuk menyamakan persepsi dan program. Serta mensosialisasi dengan calon penerima manfaat bersama dengan kelompok pendamping.

b. Penyaluran Modal Usaha, penyaluran modal untuk usaha produktif dilakukan di kantor Baitul Mal Kabupaten Aceh Utara atau di lokasi Kecamatan, dimana ada kelompok usaha dengan menandatangani berkas perjanjian yang mengikat setelah dipelajari kedua belah pihak sebagai bahan admistrasi dalam ikatan kerja sama. Setelah kedua belah pihak sepaham dan sepakat, maka perjanjian ini dilakukan dalam penandatanganan secara sah dan peraturan dan hukum.

c. Monitoring Usaha, setiap bulan tim UPZPBaitul Mal Kabupaten Aceh Utara melakukan monitoring ke lapangan dengan sistem pertemuan rutin setiap bulan. dengan tempat dan jadwal yang telah disepakati oleh semua anggota kelompok.

d. Kegiatan Keagamaan dan Pengutipan Ansuran, pengajian keagamaan yang dipandu oleh Ustad yang dihadirkan oleh Tim UPZP Baitul Mal Aceh Utara. Dengan tempat dan jadwal yang 
telah disepakati oleh semua anggota kelompok. Dengan judul "Kunci Sukses dalam Berusaha dan Menuju Jalan Kemandirian" dan tema-tema lainnya, dan juga melakukan pegutipan setoran rutin bulanan pada anggota kelompok.

Serta setiap anggota wajib menyetor infak sebesar Rp. 5.000,yang dana tersebut akan diundi kembali yang akan diserahkan kepada anggota yang beruntung dalam acara pengajian tersebut (sebagai dana infak/julo-julo) hal ini dibuat bertujuan untuk menerapkan pentingnya berinfak dan memotivasi anggota dalam menghadiri kegiatan pengajian rutin setiap bulannya.

e. Laporan Keuangan, angsuran yang disetor oleh mustahiq melalui tim pendamping yang ditunjuk di lapangan kemudian menyerahkan kepada pemegang kas UPZP untuk dilaporkan sebagai dana yang bergulir untuk dapat dilakukan perencanaan dan penyaluran kembali kepada mustahiq berikutnya.

f. Membukukan Data mustahiq, data mustahik yang telah diterima dan layak mendapatkan modal usaha, dibukukan guna memudahkan pemeriksaan.

Adapun kriteria yang ditetapkan kepada penerima zakat produktif/bantuan modal usaha yang ditetapkan oleh Badan Baitul Mal Kabupaten Aceh Utara (Tim UPZP, 2008: 6) sebagai berikut:

1. Memiliki iman dan takwa.

2. Jujur dan amanah.

3. Dari keluarga yang kurang mampu:

a. Penghasilan lebih kecil dari kebutuhan hidup sehari-hari.

b. Penghasilan di bawah Rp. 1000.000,- dan mempunyai tanggung jawab minimal 2 orang.

c. Sedang mengalami musibah dan membutuhkan modal tambahan.

4. Memiliki tempat usaha yang tetap/usaha bergerak yang terjamin.

5. Tidak bekerja sebagai PNS atau karyawan Swasta BUMN atau swasta bonafide (suami/istri/anak). 
6. Identitas dan data-data yang diajukan oleh mustahiq akan diverifikasi di lapangan oleh tim UPZP, sangat tergantung kepada fakta di lapangan yang disurvei tim UPZP.

\section{Dampak dari Penerapan Zakat Produktif}

Penerapan zakat produktif oleh Baitul Mal Kabupaten Aceh Utara telah menunjukkan dampak yang baik. Dimana dampak tersebut dapat dilihat dari usaha-usaha yang telah dilakukan oleh Baitul Mal Kabupaten Aceh Utara dalam membantu masyarakatnya dalam rangka meningkatkan kemakmuran dalam hidupnya. Sebagai lembaga pengelola zakat, Baitul Mal Kabupaten Aceh Utara terus meningkatkan kinerjanya dalam membantu mensejahterakan perekonomian masyarakat miskin, diantaranya adalah dengan memberikan zakat produktif yang bertujuan untuk meningkatkan kemakmuran masyarakat.

Beberapa penerima zakat produktif yang berhasil peneliti ketemukan menuturkan dalam versi yang berbeda terhadap dampak dari hasil dana zakat produktif. Misalnya Aminah (8 Mei 2014) yang mendapat zakat produktif sebesar Rp 3.000.000,- untuk usaha dagangnya, menuturkan bahwa peran Baitul Mal Kabupaten Aceh Utara dalam memberdayakan perekonomian masyarakat dengan memberikan dana zakat untuk usaha produktif dapat memberikan semangat kepada mustahiq-mustahiq yang kekurangan modal usaha, sehingga dengan bantuan tersebut dapat memberikan motivasi serta dapat membangkitkan semangat masyarakat untuk berhasil. Ia juga menambahkan dengan zakat produktif dari Baitul Mal bisa menjadi tambahan modal dalam usaha dagangnya tersebut.

Menurut Ibrahim (27 Mei 2014) sebagai usaha perbengkelan menyatakan bahwa, dengan kehadirannya Baitul Mal dapat memberdayakan masyarakat miskin terutama kepada masyarakat yang kekurangan modal usaha dalam melakukan usahanya. Kalau menurut saya sendiri peran Baitul Mal seperti ini perlu dipertahankan seperti Baitul Mal yang ada di negara lain terutama bagi yang menyalurkan zakat kepada Baitul Mal Kabupaten Aceh Utara, maka salurlah zakat kalau sudah sampai nishabnya. Sedangkan Muhammad (27 Mei 2014) untuk usaha dagang menyatakan bahwa 
dengan kehadirannya Baitul Mal dapat memberdayakan masyarakat miskin terutama kepada masyarakat yang kekurangan modal usaha dalam melakukan usahanya. Kalau menurut saya sendiri Baitul Mal ini perlu dipertahankan karena sangat banyak membantu masyarakat miskin khususnya di wilayah Kabupaten Aceh Utara.

Dengan demikian, ada beberapa jenis usaha yang telah diberikan modal usaha oleh Baitul Mal Kabupaten Aceh Utara diantaranya adalah penyaluran modal usaha di bidang perdagangan, pertanian, industri rumah tangga di beberapa Kecamatan dalam lingkungan Kabupaten Aceh Utara baik secara individu/kelompok. Program ini dinamakan modal usaha qard al-hasan, agar para mustahiq dapat meningkatkan taraf hidup dan mendidik mereka untuk giat bekerja. Dana yang bersumber dari Bendahara Baitul Mal Kabupaten Aceh Utara ini diberikan dalam bentuk uang tunai kepada mustahiq, dan ada juga yang diberikan dalam bentuk barang/benda.

Pemberian zakat produktif dalam bentuk modal usaha dilakukan guna memotivasi usaha yang telah ada agar berkembang, adanya suntikan dana akan menggairahkan masyarakat dalam berusaha dengan baik dan maksimal. Prospek usaha yang terdapat di sekitar lingkungan sangat mendukung terciptanya kesejahteraan hidup masyarakat. Namun tidak dikelola dan diberdayakan dengan baik maka usaha yang dimiliki tidak dapat dikelola untuk menghasilkan finansial bagi terciptanya kesejahteraan hidup masyarakat miskin.

Dengan berkembangnya usaha kecil menengah dengan modal berasal dari zakat akan menyerap tenaga kerja. Hal ini berarti angka pengangguran bisa dikurangi dan berkurangnya angka pengangguran berarti akan berdampak pada meningkatnya daya beli masyarakat terhadap suatu produk barang ataupun jasa, meningkatnya daya beli masyarakat akan diikuti oleh pertumbuhan produksi, pertumbuhan sektor produksi inilah yang akan menjadi salah satu indikator adanya pertumbuhan ekonomi (Fahmi; 2015).

Dengan demikian, zakat produktif telah memberikan dampak yang sangat penting dalam berbagai hal kehidupan umat, Dengan kata lain, penerapan zakat secara profesional dan produktif pada Baitul Mal Kabupaten Aceh Utara dapat ikut membantu kemakmuran perekonomian masyarakat lemah dan membantu pemerintah dalam meningkatkan perekonomian Negara. 


\section{Kesimpulan}

Sebagai sebuah lembaga daerah nonstruktural yang diberi kewenangan untuk mengelola dan mengembangkan zakat, wakaf, dan harta agama lainnya serta pihak penghimpun, pengelolaan dan penyaluran zakat, keberadaan Baitul Mal khususnya Kabupaten Aceh Utara diikat dengan suatu seperangkat peraturan dan yang lebih khusus adalah Qanun Aceh No. 10 Tahun 2007 tentang Baitul Mal. Zakat yang dihimpun dan disalurkan bukan hanya yang bersifat komsumtif saja, melainkan juga bersifat produktif. Penerapan zakat produktif pada Baitul Mal Kabupaten Aceh Utara adalah dengan pemberian pinjaman modal usaha dengan menggunakan pola qard al-hasan, yaitu pinjaman tanpa bunga yang tidak mensyaratkan adanya agunan dan hanya membebankan biaya administrasi berupa biaya materai dan bagi mustahiq diharuskan membayar angsuran pokok sesuai dengan perjanjian yang telah disepakati.

Dampak dari penerapan zakat produktif pada Baitul Mal Kabupaten Aceh Utara merupakan sebagai penunjang kemakmuran masyarakat Utara telah memberikan hasil yang siginifikan, diantaranya adalah dengan memberdayakan masyarakat dari ekonomi lemah, dapat memotivasi usaha yang telah ada agar berkembang, dapat menggairahkan masyarakat dalam berusaha dengan baik dan maksimal, serta dapat menghasilkan finansial bagi terciptanya kesejahteraan hidup masyarakat miskin.

\section{Daftar Pustaka}

Ahira, Anne. 2008. Pengertian Zakat Produktif, 5 juli, http://www. anneahira.com, diakses tanggal 8 September 2013.

Ahmad Azzubaidi, 1986. Zaenuddin. Hadits Shahih Bukhari, Terj. Jilid I, Semarang: Toha Putra.

Ali, Mohammad Daud. 1988. Sistem Ekonomi Islam Zakat dan Wakaf, cet. 1, Jakarta: UI Press.

Amrullah (Mantan Kepala Baitul Mal Aceh), 2014. Pro-Kontra Zakat Jadi PAD, dalam Wawancara dengan Serambi Indonesia, Jumat (7/3). 
Anwar Musaddad, M. 2010. Zakat Produktif, 5 Oktober, http:// www.zakatcenter. org/index.phd/konsultasi-zakat/175, diakses tanggal 3 Desember 2013.

Armiadi, 2008. Zakat Produktif: Solusi Alternatif Pemberdayaan Ekonomi Umat (Potret dan Praktek Baitul Mal Aceh), Cet. I, (Yogyakarta: Ar-Raniry Press Darussalam Banda Aceh \& AK GROUP Yogyakarta.

Baitul Mal Aceh, Tim UPZP. 2007. Pengelolaan Zakat Produktif Pada Badan Baitul Mal Prov. Nanggroe Aceh Darussalam, Banda Aceh: Badan Baitul Mal Prov. Nanggroe Aceh Darussalam.

Hafidhuddin, Didin. 2002. Zakat dalam Perekonomian Modern, Jakarta: Gema Insani.

http:/ / baitulmal.acehprov.go.id/index.php/news / $\mathrm{read} / 2014 / 07 / 21 / 55 /$ peran-baitul-mal-dalammenanganikemiskinan.html.

http://baitulmal-bandaaceh.blogspot.com/2011/08/optimalisasiperan-baitul-malaceh.html.

http://www.sayedmuhammadhusen.blogspot.com/

J. Moleong, Lexy. 1989. Metodologi Penelitian Kualitatif, Bandung: Remaja Rosda Karya.

Qanun Aceh Nomor 10 Tahun 2007 tentang Baitul Mal

Qardhawi, Yusuf. 2005. Spektrum Zakat Dalam Membangun Ekonomi Kerakyatan, Cet. I, Jakarta: Zikrul Hakim.

Qardhawi, Yusuf. 2007. Hukum Zakat: Studi Komparatif Mengenai Status dan Filsafat Zakat Berdasarkan Qur'an dan Hadits, Cet. X, diterjemahkan oleh: Salman Harun dkk, Bogor: Pustaka Litera Antar Nusa. 
Sartika, Mila. 2008. Pengaruh Pendayagunaan Zakat Produktif Terhadap Pemberdayaan Mustahik Pada LAZ Yayasan Solo Peduli, 1 Juli, http://journal.uii.ac.id, diakses tanggal 7 Februari 2013.

Suparlan, Parsudi. 1994. Metodologi Penelitian Kwalitatif, Jakarta: Program Pascasarjana UI.

Surya Brata, Sumardi. 2006. Metodelogi Penelitian, Jakarta: Raja Grafindo Persada.

UPZP, Tim. 2007. Laporan Kegiatan Pengelolaan Modal Usaha Zakat produktif Baitul Mal Kabupaten Aceh Utara Tahun 2007, Lhokseumawe: UPZP.

UPZP, Tim. 2008. Laporan Kegiatan Pengelolaan Modal Usaha Zakat Produktif Baitul Mal Kabupaten Aceh Utara Tahun 2008, Lhokseumawe: UPZP.

UPZP, Tim. 2012. Laporan Kegiatan Pengelolaan Modal Usaha Zakat Produktif Baitul Mal Kabupaten Aceh Utara. 